\title{
Comparative Analysis of Educational Systems of Tunisia and Egypt and the Implications to the USA Educational System
}

\author{
James M. Mbuva \\ National University \\ Rodah M. Muli \\ National University
}

The purpose of the study was to explore a comparative analysis of the educational systems of Tunisia and Egypt; and their implications on the USA educational system and their investment in the education of its citizens. Further, this study examined a broad literature review to explore geographical, historical, economic, and political factors affecting Egypt's and Tunisia's educational system. Finally, the study investigated the implications of these two African countries' study on the American Educational System regarding the funding given towards education annually. Irrefutably, these African countries are smaller, have weak political and security provisions, and have less annual revenue than the United States of America. Still, they exert intentional efforts to provide education to their citizens! The study showed that these nations value education and invest more in education than the affluent United States of America. America, though far much capable, does not budget more for education. Still, the leaders give a lot of money to other government institutions, including defense, Housing Development, Health and Human Services, and Veteran's Benefits.

Keywords: education, schooling, educational system, educational growth, spending, educational expenditure, geographical, political, economic, historical

\section{METHODOLOGY OF THE STUDY}

This study used the interpretive/constructivist research paradigm by using qualitative data collection method which include, collecting data from reports of lived life experiences, and interpretation of the written research about educational systems of Egypt, Tunisia and USA (Yanow \& Schwartz, 2015; Mertens, 2014; Denzin, 2010; Haverkamp \& Young, 2007; Willis, Jost \& Nilakanta, R. 2007; Mackenzie \& Knipe, 2006). We will apply a meta-synthesis integrating varied results of qualitative studies on these African countries and the USA (Nye, Melendez-Torres \& Bonell, 2016; Aspfors \& Fransson, 2015; Wilder, 2014; Walsh \& Downe, 2005; Bair \& Haworth, 2004).

\section{LITERATURE REVIEW}

Indeed, this literature review section of the study will explore factors such as geographical, historical, economic, and political, which affect the educational system of Egypt, Tunisia, and the implications of the 
study of these two African countries have on American Educational System. True, these countries are smaller and have less annual revenue than the United States of America, but we want to see what they do in their efforts to educate their citizens! We want to examine their annual budget towards education, and we believe the study will reveal the truth about this subject.

\section{Comparative Analysis: Educational Systems of Tunisia and Egypt \\ Geographical Factor}

The geographical factors include Influence, the Mediterranean Sea border, and French culture.

Geographical Influence. Geography is the first factor that influenced education. One of the factors that influence the development of the country is the location. As we read in the literature, the modern countries situated near the Mediterranean Coast came into being due to outside influences and international struggle. Undoubtedly, most of these countries consciously or unconsciously continued their thought process and behavior as transmitted by their forefathers; however, they continued to obey Western Civilization thinking and doing things (Bozeman, 2017).

Mediterranean Sea Border. Both Tunisia and Egypt have similarities in that the Mediterranean Sea borders them. Tunisia is located on the northern tip of Africa and borders the Mediterranean Sea, Algeria, and Libya, while Egypt, situated on the northeast corner of Africa, touches the Mediterranean Sea. Tunisia has a Mediterranean climate towards the coast, while other parts are deserts (Kchih, Perrino \& Cherif, 2015; Pilkey, Heron, Harbridge, Kamens, Keer, \& Thornton,1989). Similarly, Egypt has a Nile river that flows from the North and provides irrigation, food, and water transportation (Agrawala, Moehner, El Raey, Conway, Van Aalst, Hagenstad, \& Smith, 2004).

French Culture. Tunisia's Influence is by French culture after being its protectorate for $75 y e a r s$ while Egypt was influenced by the British, and such Influence promoted education (Mortimer-Murphy, 2020; Perkins, 2014; Lewis, 2013; Battenburg,1997; Mckay, 1945; Hatem,1994; Cain, 2006; Galbraith, \& alSayyid-Marsot,1978; Sayed, 2006; Cook, 2001).

\section{Historical Factor}

The historical factor includes the historical Influence, curriculum, and religious education, Egypt curriculum has become a model, rapid growth of Egyptian youth, emergency of informal education, Tunisia education is compulsory, and students' difficulties finding a job.

Historical Influence. The second factor that influenced education in Tunisia and Egypt is History. Historically education in the Arab world was closely linked to religious education (Cook, 2001). Indeed, education was both worship and a school (Faour, 2014; Stepan, 2012; Starrett,1998). The clergy served as both the teacher and the administrator. During the Ottoman rule in the Nineteenth Century, Christians Missionaries from Europe and the United States established K-12 Schools in Lebanon, Syria, Egypt, Jordan, and Palestine (Pikkert, 2008; Makdisi, 2011; Erhan, 2000; Doğan, 2011). However, the Islamic association in Lebanon and other Arab countries developed their schools that taught Islam and basic subjects (Zakharia, 2009; Boyle, 2006; Neill, 2006; Irani \& Funk,1998; Ghaith \& Shabaan,1996).

Curriculum and Religious Education. Today in many Arab countries, the curriculum includes Islam religious education in the public school system as a separate study (Jules, \& Bouhlila, 2018; Feuer, 2017; Feuer, 2014; Faour, 2012; Katz, 2012; Bouhlila, 2011; Boyle, 2006; Neill, 2006; Anzar, 2003; Cook, 1999). Including religious education in the curriculum vary from country to country. There is a significant difference between Egypt and Tunisia curriculum concerning the content, learning objectives, and teaching (Faour, 2012; Bouhlila, 2011; Valverde, 2005; Akkari, 2004). For example, the Tunisian school curriculum for different subjects aims more explicitly than in Egypt the development of the universal values of freedom, cooperation, equality, social justice, and respect of others (Faour, 2013; Faour, 2012; Bouhlila, 2011; Cook, 1999; Dwyer, 1991).

Egypt Curriculum Has Become a Mode. However, the Egyptian curriculum has become a model for the other Arab education system in recent years. The president guarantees that all university graduates would find employment (Loveluck, 2012; Cochran, 2012; Holmes, 2008; Cook, 1999). Due to high 
demand, the level of available State resources caused by providing quality education deteriorate (Lloyd, El Tawila, Clark \& Mensch, 2003).

Rapid Growth of Egyptian Youth. Indeed, the rapid growth of Egyptian youth led to hiring insufficiently qualified teachers and placed immense strain on schools' facilities. Different schools in urban areas started to operate in shifts (Qutb, 2016; Hyde, 2013; Moon, 2007; Assad \& Barsoum, 2007). Today the impact of such a trend in public sector education has led to a poor teacher-student ratio, one to fifty students, and investing in school has not kept pace due to the rapid increase in students (Ajayi, Abina \& Lawal, 2020; Ille, 2015; Lloyd, El Tawila, Clark \& Mensch, 2003). To alleviate such pressure, many schools operate in shift students attending part-time.

The Emergence of an Informal Education. The overcrowded, inadequate quality training and the limited budget have led to the emergence of an informal education sector where torturing filled the educational gap left by the formal schooling system (Loveluck, 2012; Ille, 2015; Lloyd, El Tawila, Clark $\&$ Mensch, 2003). Hence, over 60 percent of investment is spent on private tutoring, and high demand for personal training goes with those students who cannot afford private lessons disadvantaged (Jobhy, 2012; Dang \& Rogers, 2008).

Tunisia Education Is Compulsory. In contrast to Egypt, Tunisia education is compulsory for all children ages 6-16 and is free. As such, children enroll in primary school, and nearly one out of sixth of its young people go to attend higher learning (Siala \& Ammar, 2014; Frin \& Muller, 2012; Loveluck, 2012; Arfaoui, 2011; Daoud, 2007; Daoud, 2011; Oreopoulos, 2006; Sultana, 2004). With all the efforts of the competence approach to primary education, we find that more than three-fourths of the population in Tunisia is literate, although the rate for men is higher than women (Loveluck, 2012; Sultana, 2004). However, just like Egypt, the number of schools, students, and teachers has created financial strains since education is one of the most significant shares of the annual budget (Frini \& Muller, 2012). Students have no other way but to turn to alternative private funding.

Students' Difficulties Finding Jobs. Like many other parts of the developed and developing world, Tunisia students have found difficulties finding jobs. However, in recent years, the emphasis has been placed on technical, vocational, teacher and agricultural training (Biavaschi, Eichhorst, Giulietti, Kendzia, Muravyev, Pieters \& Zimmermmann, 2012; Loveluck, 2012; Oketch, 2007; Middleton \& Ziderman, 1997; Middleton \& Demsky, 1989).

\section{Economics Factor}

Economics as Part of the MENA

The third factor influencing education in Tunisia and Egypt is economics as part of the MENA region (Barakat, Elgazzar, \& Hanafy, 2016; El Said \& Harrigan, 2014; Belloumi, 2014; O'Sullivan, Rey, Mendez, 2011; Harrigan \& El Said, 2010). The MENA region encompasses many different countries such as monarchs and republics regions; countries considered oil exporters and importers. Cultures under AngloSaxon Influence, entirely Arabs societies, Arab- Berbers and African Muslims (Marchesi, 2017; Talani, 2015; Belloumi, 2014; Zdanowski, 2014; Helmy 2013; Eltkhatash, 2013; Isakhan, Monsouri, Akbarzadeh, 2012; Alexander, 2010; The wealth of some countries is based on oil, gas and is susceptible to world price volatility.

\section{Systemic Corruption}

Among the Middle Eastern countries, there have been reports that "Systemic corruption in the Arab region is a serious hindrance to economic growth and business prosperity" (Jamali, Lanteri \& Walburn, 2013). Evidently, in recent years the MENA region has been experiencing an economic downturn in economic growth at the global level due to corruption, embezzlement, misuse of public funds, and money laundering (Azoury, 2017; Subramarian, 2016; Biygautane, 2015; Nugent, 2012; Odeh, 2012).

\section{Socio-Economic Inequality}

For example, in Tunisia, "socio-economic inequality, youth unemployment, corruption, and government oppression in the making of the Tunisian uprisings" grievances were the critical factor in the 
2011 uprising (Kapoor, 2020; Yaghi, 2018; Pellizar, Assaad, Krafft, \& Salemi, 2017; Hasse, 2015; Farquhar, 2015; Beissinger, Jamal \& Mazur, 2015; Breuer \& Landman, 2015; Plaetzer, 2014; Rane \& Salem, 2012; Kaboub, para. 1; Alexander, 2010). To address such complaints has been undermined by new economic strains.

\section{Damaged Tunisia's International Credit Rating}

Tunisia's largest trading partners are countries of Europe. Hence, due to Europe's political instability, security trends, and slow economy, the decline in tourism and foreign direct investment (FDI) damaged Tunisia's international credit rating (Zaiane, 2018; Matta, Appleton, \& Bleaney, 2018; Youssef, 2018; Mnif, 207; Beyer, Jensen, \& Johnson, 2015; Oxford Analytica, 2016; Naciri, 2015; Arieff, Humud, 2015; Arieff, 2011). All these economic situations have impacted education leading to a lack of funding in school education.

\section{Political Factor}

\section{Politics}

The fourth factor that influenced education is politics. The Egyptian education system was influenced by political development (Coleman, 2015; Schomaker, 2015; Henry \& Springborg, 2010; Ibrahim, 2010; Baraka, 2008; Sayed, 2006; Cook, 1999; Hatem, 1992; Faksh, 1980). Ottoman rulers in the early Nineteenth Century first introduced the European type of system; and, during Ottoman rule, they developed primary and secondary schools and high education to cater to the military (Barkey \& Gavrillis, 2016; Burcak, 2008; Horwitz, 2004; Makdisi, 2000; Gocek, 1993; Celik, 1993; Kuhnke, 1990). Education was free until the British occupied Egypt and changed fees. In 1950 under President Nasser, education became the central part of the government.

\section{Tunisia Legal System}

In contrast, Tunisia's legal system stands on French civil law with some influence from a liberal interpretation of Islamic law (Esmaeili, 2010; Mashhour, 2005; Abu-Odeh, 2004; Mahoney, 2001; Badr, 1977). Since independence, a prominent feature of Tunisian social policy has been an effort to improve the status and lives of women (Anderson, 2014; Perkins, 2014; Boittin, 2010; Grami, 2008; Wing \& Kassim, 2007; Hessini, 2007; Mir-Hosseini, 2006; Charrad, 1997; Mayer, 1995; Obermeyer, 1994).

\section{Women Status}

Compared to Egypt, women in Tunisia have enjoyed greater equality in political, social, and economic roles after the Progressive Code of personal status introduced in 1956 was amended (Charrad, 2012; Dalmasso \& Cavatorta, 2010; Grami, 2008; Coleman, 2004; Murphy, 2003). In Egypt, despite the progress in the past gender inequality exists, women social and economic roles are lacking behind and sometimes silenced (Benjamin, 2013; Littrell \& Bertsch, 2013; She, 2012; Loveluck, 2012; Staudt, 2010; Yount, 2005; Shabaya \& Konadu-Agyemang, 2004; Murphy, 2003; Goodwin, 2002; Al-Ali, Ali, \& Nadje, 2000; Murphy, 1996).

\section{Tunisia Educational System}

The educational system of Tunisia divides into three basic levels that include: (a) primary education (nine years), (b) secondary education (4years), (c) and higher education (four years). On the other hand, Basic education consists of two phases such as primary education (six years), (b), and preparatory education (three years). 


\section{TABLE 1 \\ TUNISIA'S EDUCATIONAL SYSTEM}

\begin{tabular}{llc} 
Primary & Basic Schooling & 9 \\
\hline Secondary & Upper Secondary & 4 \\
\hline Vocational & Vocational Education & \\
\hline Tertiary & University First Stage & 2 \\
\hline Tertiary & University Second Stage & $1-3$
\end{tabular}

\section{Educational Background Tunisia}

1. Colonized by the French.

2. In 1956, Tunisia, as an independent State, started its very own educational system.

3. French as an efficient medium of instruction is the ultimate legacy of France to the Tunisian education.

4. Free and obligatory primary education policy is implemented throughout the nation.

5. The Tunisian education system is based on the French model that emphasized Arabizing the curriculum.

Source: https://www.studycountry.com/guide/TN-education.htm

\section{Types of Schools}

1. Private Schools:
(a) Roman Catholic Schools

(b) Jewish Schools

\section{Religious Schools:}

(a) Koranic (Islamic) kindergartens in Tunisia offer training to young Tunisians from the age of four in Muslim religious studies and the language of the Koran.

(b) In addition, one of the seven public universities in Tunisia-Universit,é Ezzitouna-is dedicated to training imams and Koranic scholars.

\section{Tunisia's Educational Rate}

1. In 2015 , the adult literacy rate for Tunisia was $81.1 \%$.

2. The adult literacy rate of Tunisia increased from $48.2 \%$ in 1984 to $81.1 \%$ in 2015 , growing at an average annual rate of $6.36 \%$.

\section{Educational Expenditure}

1. Public spending on education.

2. Tunisia expenditure in primary education in 2005 , is $34.5 \%$.

3. Tunisia expenditure in primary education was $27.7 \%$ in 2008 , down from $34.3 \%$ in 2005 .

4. Total (\% of government expenditure) in Tunisia was reported at $22.9 \%$ in 2015 .

5. According to the World Bank collection of development indicators, we compiled from officially recognized sources.

Source: https://knoema.com/atlas/Tunisia/topics/Education/Expenditures-on-Education/Expenditure-in-primaryeducation 


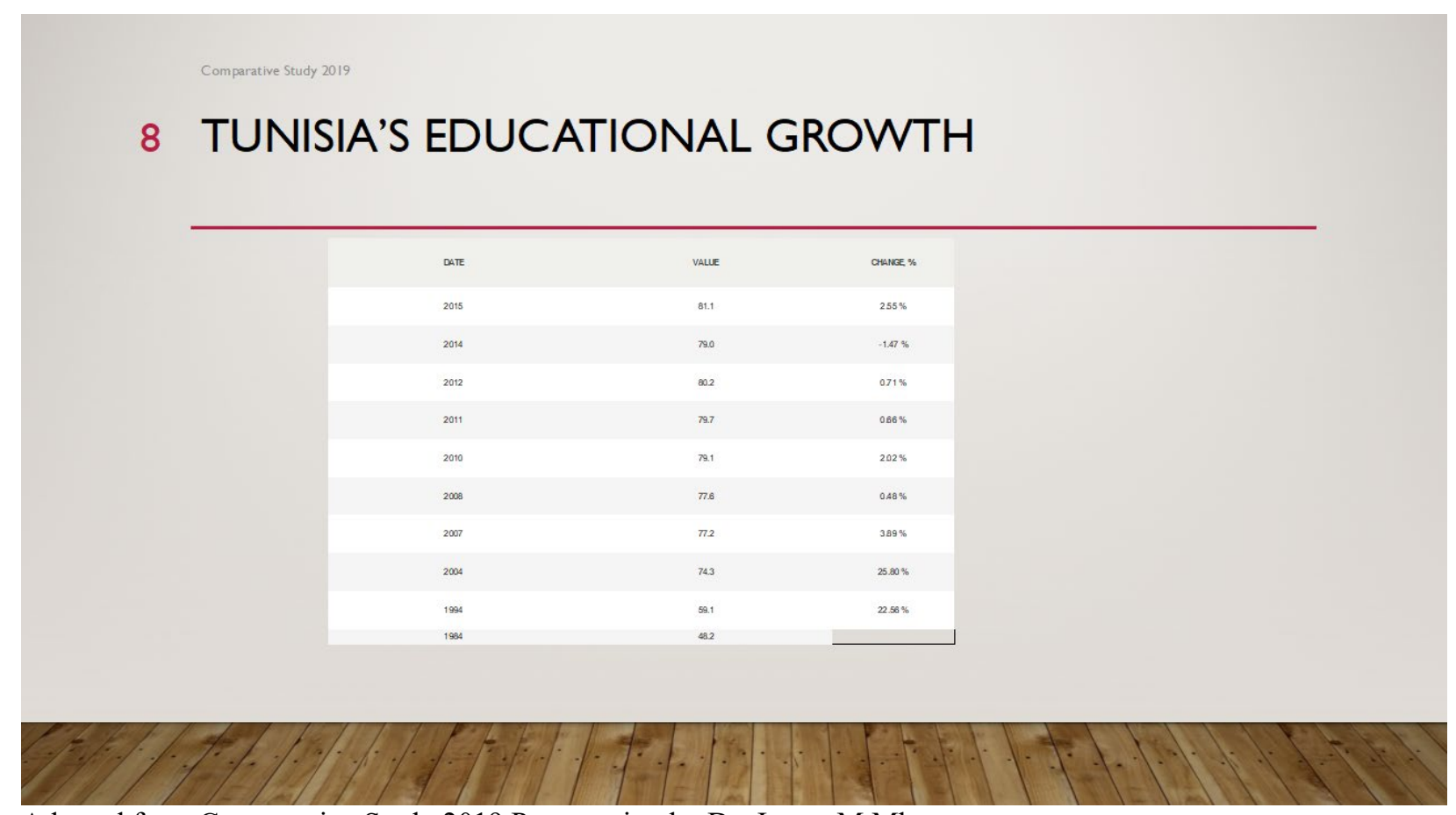

Adapted from Comparative Study 2019 Presentation by Dr. James M Mbuva

\section{Egyptian Educational Background}

1. Modern Education in Egypt came under the auspices of Ottoman Pasha Muhammad Ali during the early 1800 s.

2. He started a dual system of Education at the time: one serving the message attending traditional schools (Mansourya) and another called Madrasa (Arabic word for school) for the elite civil servants. $\mathrm{t}$

3. The Mansourya taught students the basics of reading and writing throughout memorizing and reciting Qur'anic verses with no emphasis on experimentation, problem-solving or learning-bydoing. At the same time, the Madrasa offered a more modern educational pedagogical.

Sources: (Allard, M. J.; McKay, P. R. "World Education Encyclopedia "; Hartmann, Salah (2008). "The informal market of Education in Egypt: Private tutoring and its implications

\section{Educational System}

1. The public education system in Egypt

2. It consists of three levels:
(a) The primary education stage for 4-14 years old:
(b) Kindergarten for two years
(c) Followed by a primary school for six years and preparatory school (ISCED Level 2) for three years. Education is made compulsory for nine (9) academic years between the ages of 4 and 14 . In the 2000 s, there was an incline to privatize secondary education by exerting private tutoring in technical and general schools (Sobhy, 2012). That is why Egyptian's call for educational reforms was mandatory.


TABLE 3

EDUCATIONAL SYSTEM

Comparative Study 2019

II EGYPTIAN EDUCATIONAL SYSTEM

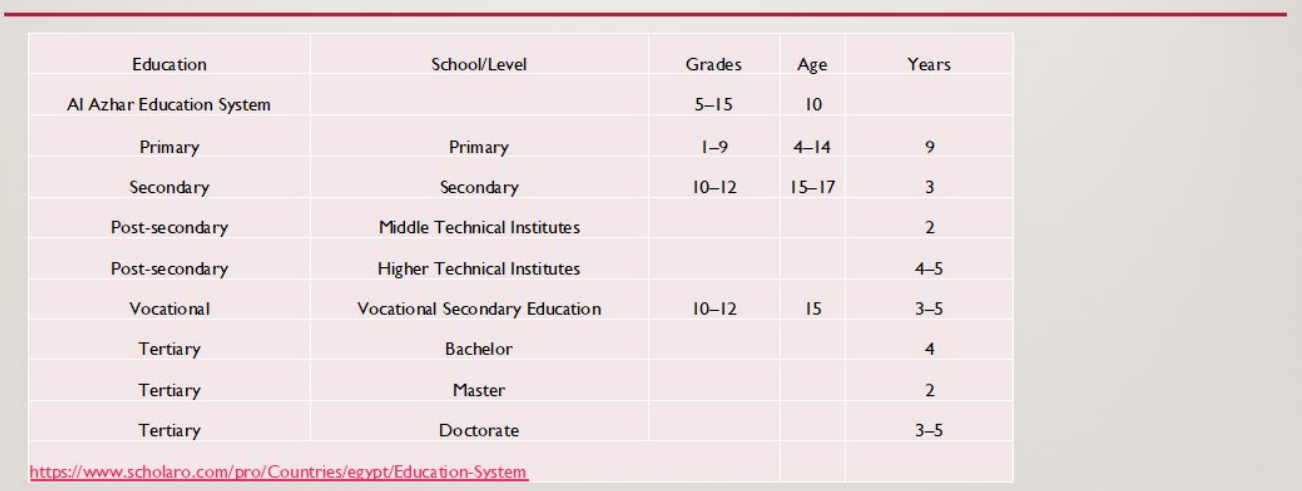

Adapted from Comparative Study 2019 Presentation by Dr. James M Mbuva

\section{Educational Rate}

1. The overall literacy rate in Egypt is 72 percent as of 2010,

2. By gender.

(a) $80.3 \%$ for males.

(b) $63.5 \%$ for females.

Source: "The World Factbook — Central Intelligence Agency". Cia.gov. Retrieved Oct 16, 2017.

\section{Types of Schools}

1. Government schools.
(a) Arabic.
(b) Experimental language schools

2. Private schools.
(a) Ordinary schools.
(b) Language schools.

3. Religious schools.
(a) Azhar Schools.
(b) Roman Catholic schools.

4. International Schools.
(a) British.
(b) American.
(c) French.

\section{Egyptian Educational Growth}

1. The number of Egyptians enrolled in upper-secondary education has mushroomed by an enormous 65 percent over the last decade. 
2. This trend is driven by population growth as well as by increasing participation rates.

3. At this stage of education, the net enrollment ratio grew from 62.5 percent in 2014 to 67.5 percent in 2017. Feb 21, 2019

Source: https://wenr.wes.org/2019/02/education-in-egypt-2

\section{Egyptian's Government Making Education a Priority}

1. In recent years the Government of Egypt has given greater priority to improving the education system.

2. The government is responsible for offering free education at all levels.

3. The current overall expenditure on education is about 12.6 percent as of 2007.

\section{Educational Expenditure}

1. In $20113.5 \%$ of GDP (around \$9.5bn) was spent on education.

2. $\$ 300$ per student each year.

3. In the $2013 / 14$ fiscal year, this amount had risen only slightly to $3.9 \%$ of GDP, equal to $\$ 11.1 \mathrm{bn}$.

4. The government's new budget for fiscal year 2018-19 is expected to allocate LE115 billion to education, up only 8 percent from the previous budget allocation of LE106.5 billion.

Sources: https://oxfordbusinessgroup.com/overview/focus-point-increase-spending-should-support-aim-improvingquality-well-access; https:/timep.org/commentary/analysis/egypts-long-road-to-education-reform/

\section{Challenges of Egyptian Education}

1. Low quality of educational experience.

2. Educational is unequally distributed.

3. Shortage of skilled and semi-skilled workforce.

4. Quality of teachers that teach in public schools.

5. Significantly higher enrollment rates in wealthier regions at both the primary and secondary levels.

6. This confirms that more efforts are needed to reduce the wealth gap in educational attainment.

7. Need for educational reform.

Source: "World Bank(2008), The Road Not Traveled: Education Reform in the Middle East and North Africa". Wds.worldbank.org. Retrieved Oct 16 2017; https://timep.org/commentary/analysis/egypts-long-road-toeducation-reform/

Implications to The United States of America

1. Though affluent USA Education lags worldwide.

2. Science performance worldwide grading 496 (\#24, while Singapore is \#1/556.

3. Mathematics performance worldwide grading 470 (\#39, while Singapore is \#1/564.

4. Reading performance worldwide grading 497 (\#24, while Singapore is \# 1/535.

Source: https://www.pewresearch.org/fact-tank/2017/02/15/u-s-students-internationally-math-science

\section{What Happened?}

1. As recently as 20 years ago, the United States was ranked No.1 in high school and college education.

2. Much of the boom in American education during the second half of the 20th century was fueled by the Montgomery G.I. Bill, which provided scholarships and student loans to veteran service personnel returning from World War II.

3. Having matured on the battlefield, thousands of returning troops eagerly seized the opportunity to improve their postwar prospects in the civilian world, leading to a transformation of the American middle class in the 1950s and 1960s.

\section{Implications}

1. In 2009, the United States was ranked 18th out of 36 industrialized nations. 
2. Ranking 17 th in 2013.

3. Ranking 14th in 2015 .

4. Over that time, complacency and inefficiency, reflective of lower priorities in education and inconsistencies among the various school systems, contributed to a decline.

5. The United States still ranks No.1 in the world's higher education institutions (i.e., colleges), including their ability to help graduates transition into the job market. Still, the cost of higher education has become a challenge in itself.

6. Concurrent with any even minor decline in American education, one has to consider the ambitious increases in education among the countries that have surpassed it.

7. Another factor is the diversity of people entering the American educational melting pot. The top three leaders in general education, Finland, Japan, and South Korea, have relatively smaller and much more homogeneous populations, making it easier to maintain a consistent standard.

Source: https://www.historynet.com/was-the-usa-ever-no-1-in-

education.htm; https://rankingamerica.wordpress.com/tag/education/

\section{USA Educational Expenditure}

1. Total expenditures for public elementary and secondary schools in the United States in 2015-16 amounted to $\$ 706$ billion, or $\$ 13,847$ per public school student enrolled in the fall (in constant 2017-18 dollars).

2. Total expenditures included $\$ 12,330$ per student in current spending. Also, it has salaries, employee benefits, purchased services, tuition, and supplies.

3. Total expenses also included $\$ 1,155$ per student in capital outlay (expenditures for property and buildings and alterations completed by school district staff or contractors) and $\$ 362$ for interest on school debt.

Source: U.S. Department of Education, National Center for Education Statistics. (2019). The Condition of Education 2019 (NCES 2019-144), Public School Expenditures; https://nces.ed.gov/fastfacts/display.asp?id=66

1. Funding of education. Not enough compared to other countries.

2. The United States was one of only five countries in the OECD to cut education funding in the years before the OECD study.

3. The OECD report for 2017 found that education spending in the U.S. decreased $3 \%$ between 2010 and 2014 while spending in other nations was up 5\%.

4. Education Spending as a Percentage of GDP

5. Among the 34 OECD countries reporting data in 2015, 17 countries spent more than the average percentage $(5 \%)$ of GDP on total government and private expenditures on education institutions for OECD countries.

Norway spent the most on education as a percentage of GDP at $6.4 \%$, followed by New Zealand at $6.3 \%$, the United Kingdom at $6.2 \%$, and the United States at 6.1 percent.

\section{TUNISIA AND EGYPT ARE 3RD WORLD COUNTRIES}

The expenditure on education of these 3 rd world countries is encouraging. Have a look.

\section{Tunisia}

1. 2005 spent $34 . \%$ On education.

2. 2008 spent $27.7 \%$.

3. 2015 spent $22.9 \%$

\section{Egypt}

1. 2011 spent $3.5 \%$.

2. $2013 / 14$ spent $3.9 \%$. 
3. $2018 / 19$ spent $12.6 \%$

\section{IMPLICATIONS OF THE FINDINGS OF THE STUDY TO USA EDUCATIONAL SYSTEM}

Currently, the USA is not in the same situation it enjoyed 30 years ago. Things have changed. Notably, the winds of globalization and the emerging power of the "rising rest" such as the European Union, China, Russia, and others are conspicuous. The trade wars that the USA has engaged with the allies are slow and sure ending USA supremacy in the global political and economic arena, thus bringing to an end of "Western hegemony" as we know it (Kupchan, 2012, para 2).

However, the USA still has geographical, historical, political, and economic advantages that positively affect her children's education.

\section{Geographical Factor}

Geographically, the United States of America is well situated. It enjoys excellent trade with the closest neighbors, such as Canada and Mexico. Further, America trades with Latin America, Australia, Japan, Asia, and the European Union.

\section{Historical Factor}

Although the British Empire ruled the USA, it secured its independence after bloody wars. The USA has experienced wars which include the colonial war of 1620-1774; battle of freedom/revolutionary war of 1775-1783; the war of 1812; Mexican war of 1846-1848; civil war of 1861-1865; Spanish-American war of 1898-1901; World War I of 1917-1918; and the World War II of 1941-1946 (Leland, 2010; Baker, 1917). Evidently, after World War I \& II, the USA emerged as an industrial power, farming becoming a booming industry, discovery of machineries such as that which built steamboats, minerals, and the like led to the establishment of a stable USA into the close of the 20th century (Crisman, Lees, \& Davis, 2013).

\section{Political and Economic Factors}

With the geographical position, historical background of victories over the wars, the USA became a superpower. It exercised its pollical muscle by creating allies who enriched the country economically by selling ammunition, agricultural products, and intellectual capability, which has helped make the technological and prosperous world we see. Literary, the USA has created the world power and economy experienced by almost all world countries, some, unfortunately, have become enemies.

\section{The USA Dilemma of Educating Her Children}

Although America has the best geographical positioning, historical strength, winning wars and establishing allies, political and economic capital, America lags in her children's education, there is the disparity of the haves, and the have nots, the rich and the poor communities (Brady, Eastman, \& Packer, 2000). As Wexler shows, the hidden knowledge gap is the hidden cause of America's broken education system (Wexler, 2020). Wexler shows that "the elementary school curriculum's intense focus on decontextualized reading comprehension 'skills' at the expense of actual knowledge" is the reason America lags compared with other nations' educational systems (2020, para. 1). America should prioritize its expenditure to provide quality education to all children, giving them the vocabulary and the learning experiences they need to succeed in the 21 st competitive world. Agreeably, there is no more blaming the American teachers, buildings, and accountability, but American leadership and the citizens should rise to think and save the educational crisis.

The need for quality education for America's children is reachable. The United States of America has created colossal wealth; hence it can invest in education to educate American children by providing the best education for the diverse student population in the cities and the suburbs.

For analysis, we will use the data from the charts below to show the annual income of the USA, expenditure, and total percentage allocated on the programs of educating America's children. 


\section{FIGURE 1 \\ EDUCATION RECEIVES 6\% COMPARED TO OTHER INSTITUTIONS OF THE GOVERNMENT}

\section{President's Proposed Discretionary Spending}

(FY 2013)

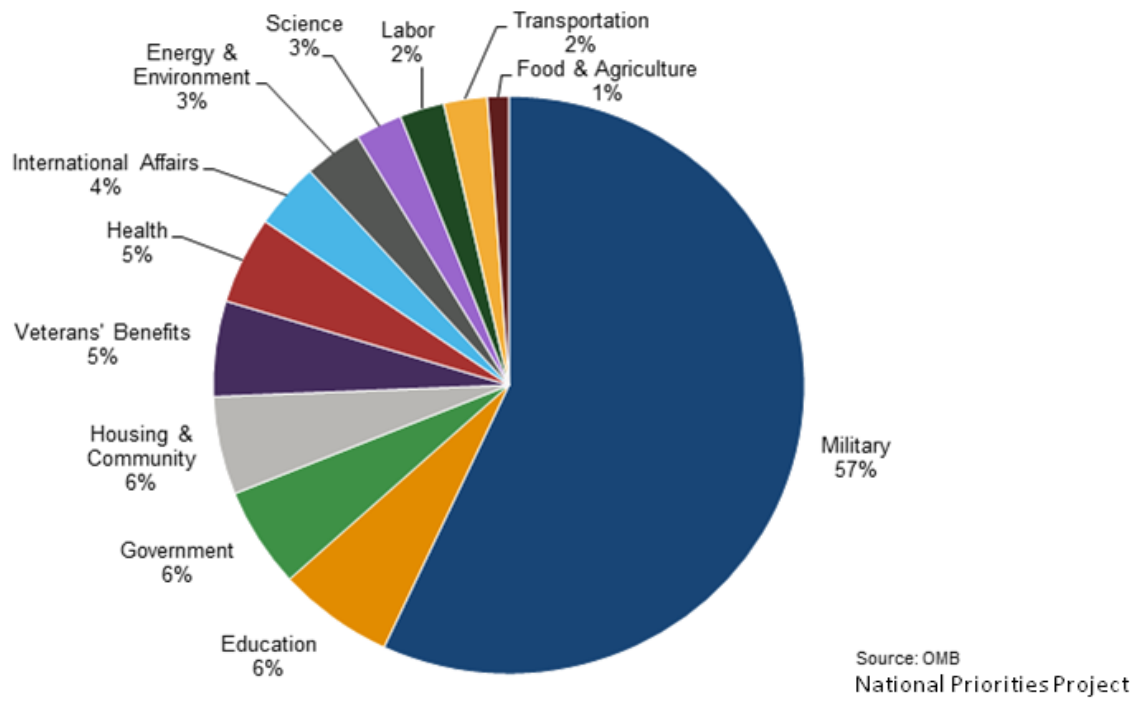

It's impossible to talk about the budget deficit without talking about the military budget. It has the largest share of discretionary spending.

Discretionary spending refers to the portion of the budget which goes through the annual appropriations process each year. In other words, Congress directly sets the level of spending on programs which are discretionary.

http://tippingpointnor thsouth.org/5percent

Adapted from OBM National Priorities Project

As shown in the president's discretionary spending, you find that education was awarded $6 \%$, whereas the military was awarded $57 \%$. Although other sectors such as housing and community, government, receiving $6 \%$, and veterans receiving $5 \%$, United stated should allocate more money towards her children's education. Hence, granting a more considerable percentage in education. There is enormous parity between the spending on education and the money spent on the military, 57\%. Indeed, America must be well prepared in case of any military war and conflict arising from outside its borders and buying ammunition and instruments of war is essential. However, this should not be at the expense of America's children, youth, and young adults. 


\section{FIGURE 2}

\section{FEDERAL BUDGET, 2014}

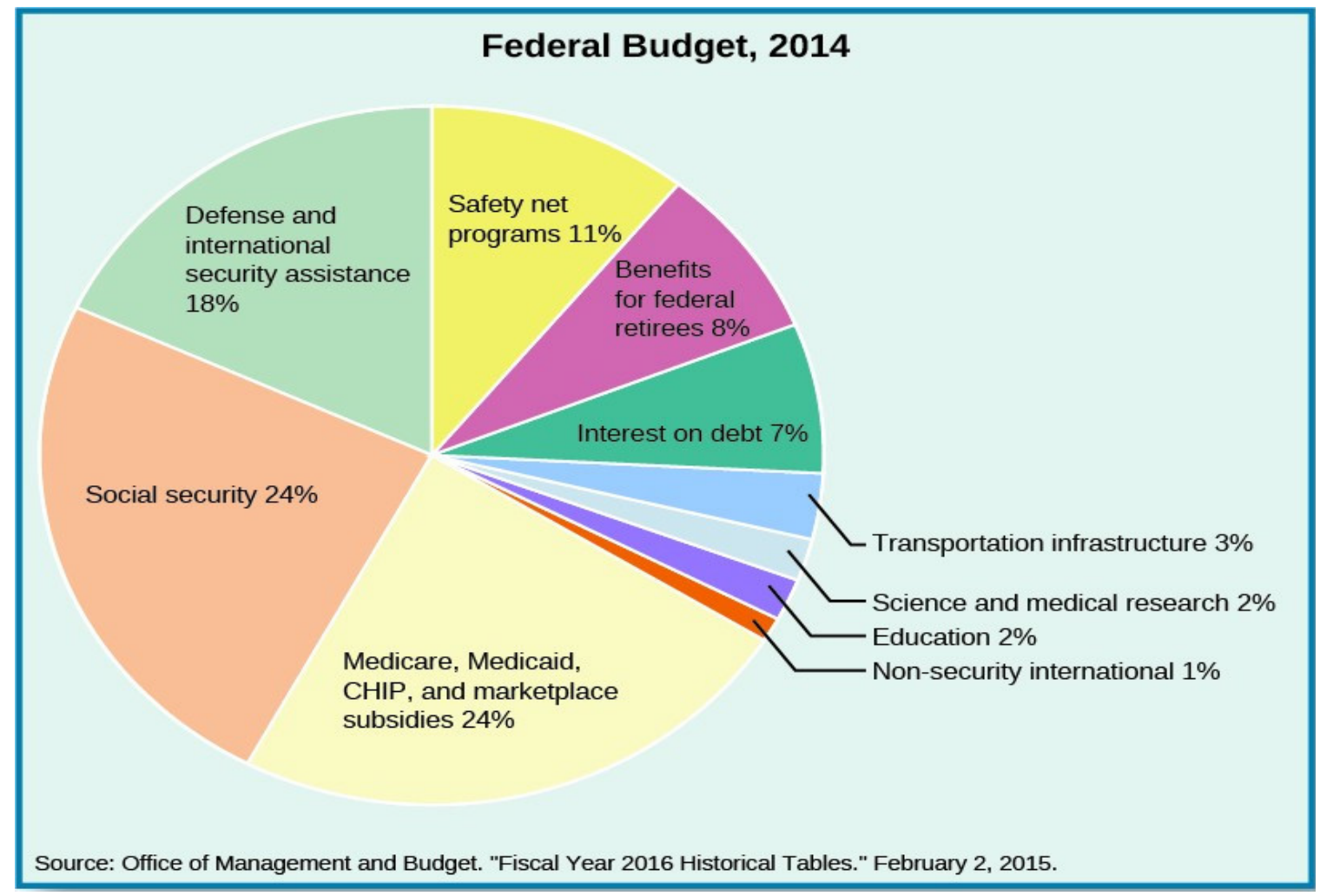

The 2014 Federal Budget is a shocker as we find that educational allocation is only $2 \%$. In contrast, other government institutions have received higher allocation such as Social Security 24\%, Medicare, Medicaid, CHIP, AND marketplace subsidies 24\%, Defense and international security assistance 18\%, SafetyNet programs 11\%, and Benefits for federal retirees $8 \%$. Irrefutably, all other aspects of America's life are essential; however, educating her children receives too little money in the 2014 budget. 
FIGURE 3

DISCRETIONARY SPENDING 2015: \$1.11 TRILLION

\section{Discretionary Spending 2015: \$1.11 Trillion}

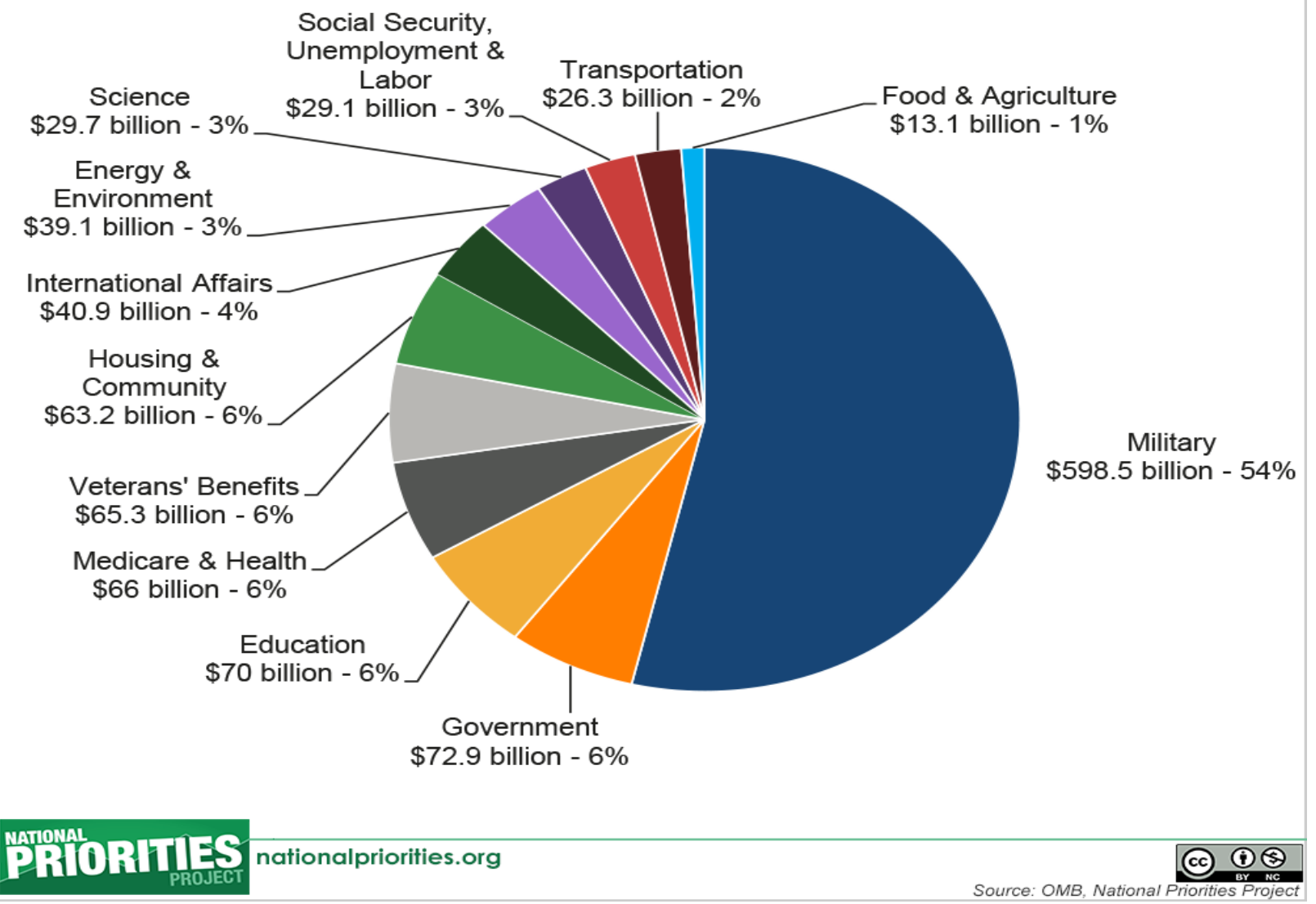

Adapted from National Priorities.org

In the 2015 discretionary spending, there is a drastic change, for you find that education got $\$ 70$ billion equivalent to $6 \%$ a little more than Housing and Community receiving $\$ 63.2-6 \%$, Veteran's Benefits $\$ 65.3$ billion $-6 \%$, Medicare and Health receiving $\$ 66$ billion $-6 \%$. However, education is receiving lower than the government receiving $\$ 72.9$ billion $-6 \%$, and the Military receiving $\$ 598.5-54 \%$. Again, America is using half of its spending on Military than education 


\section{President's Proposed \$4.1 Trillion Total Spending Budget (FY 2016)}

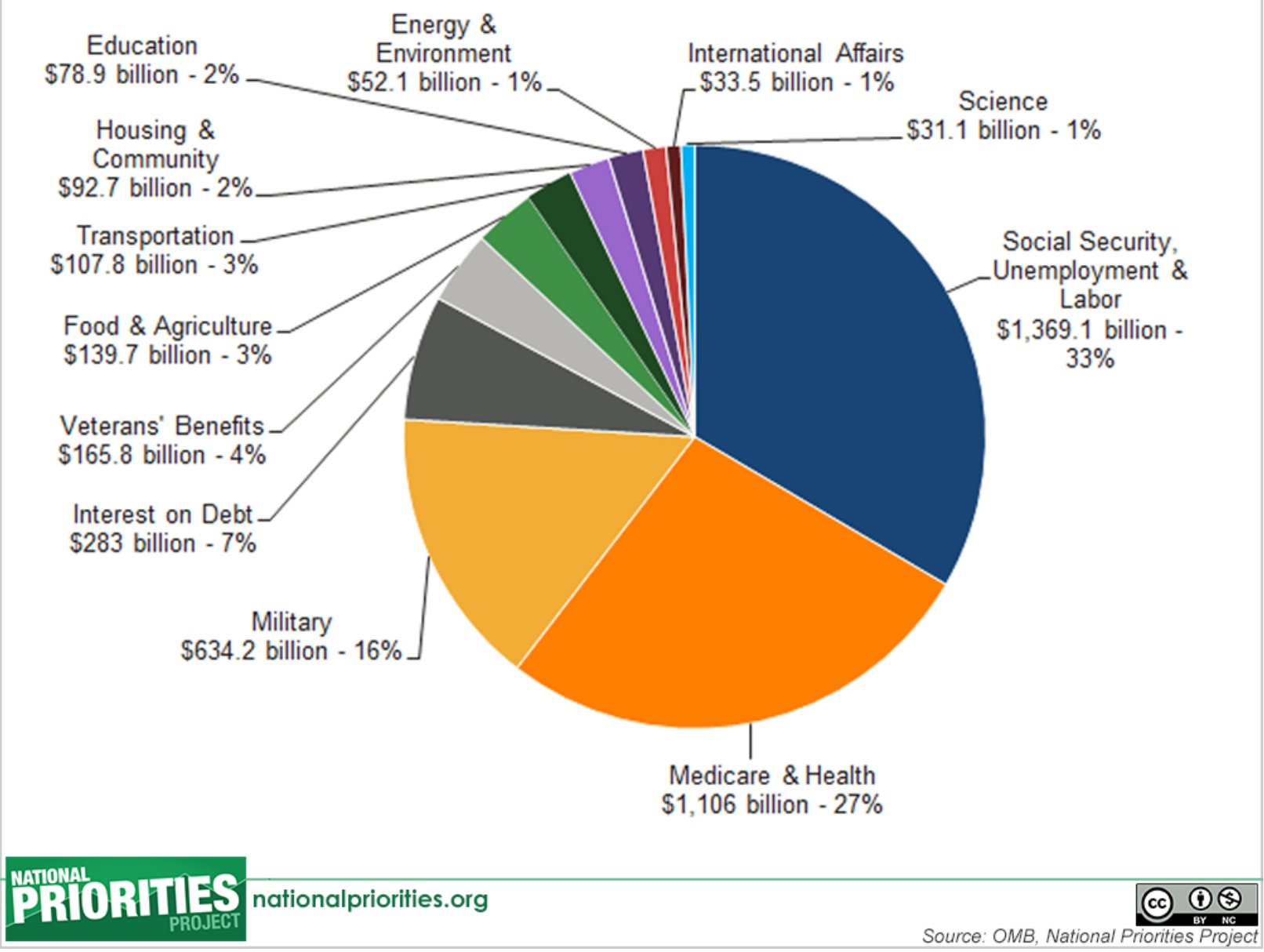

Adapted from nationalpriorities.org

In 2016 president's proposed $\$ 4.1$ trillion total spending budget, the education sector is receiving $\$ 78.9$ billion $-2 \%$, less than Housing and Community receiving $\$ 92.7$ billion $-2 \%$, Transportation receiving $\$ 107.8$ billion - 3\%, Food and Agriculture receiving 139.7, Veterans' and Benefits receiving $\$ 165.8$ billion $-3 \%$. Unlike education, the big spenders include Military $\$ 634.2$ billion - 7\%, Medicare and Health receiving $\$ 1,106$ billion - 27\%, and Social Security, Unemployment and labor receiving \$1,369.1 billion$33 \%$. 
FIGURE 5

PRESIDENT'S PROPOSED \$4.2 TRILLION TOTAL SPENDING IN 2017

\section{President's Proposed \$4.2 Trillion Total Spending (FY 2017)}
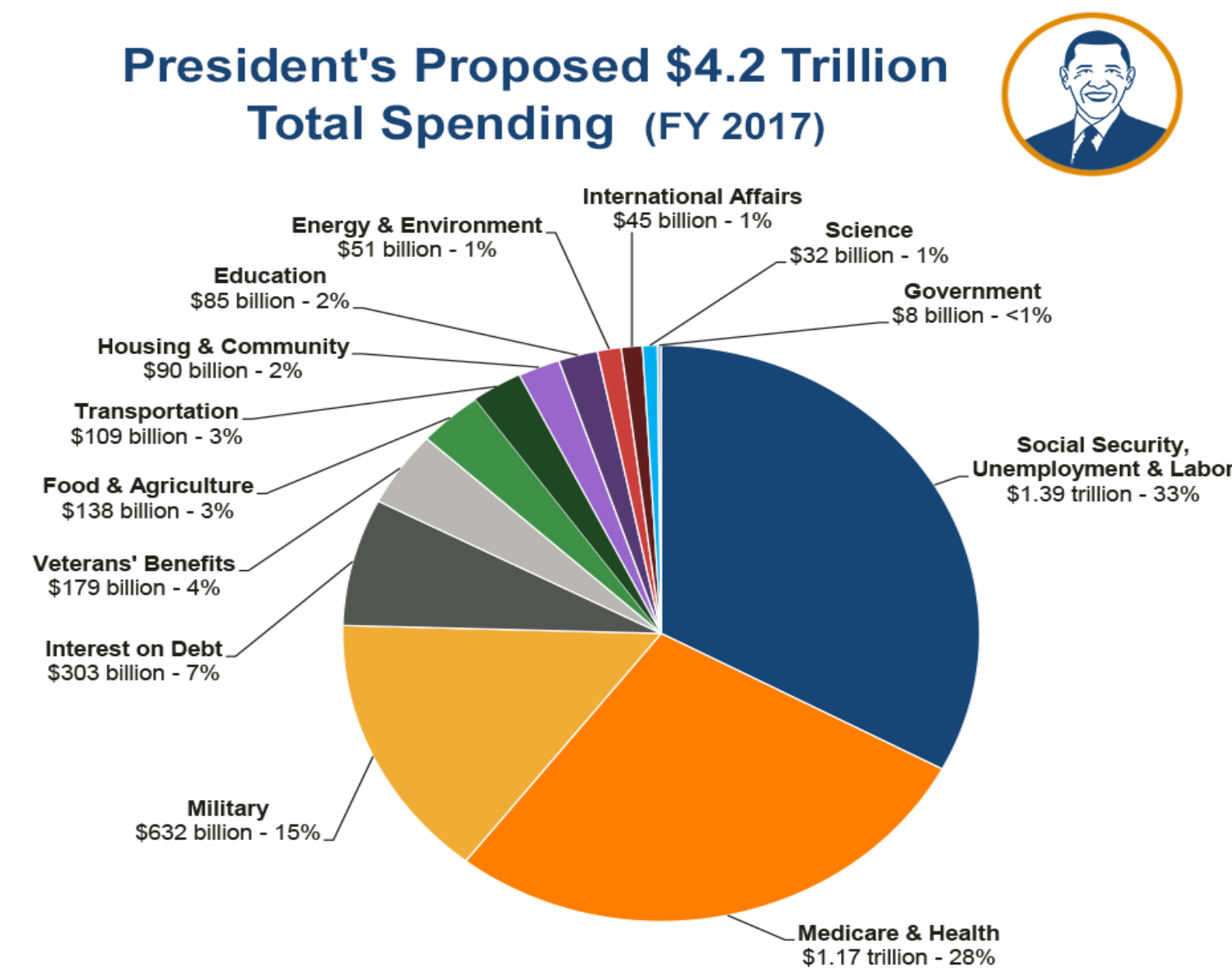

Adapted from nationalpriorities.org

Observing 2017, you will find that Education receives less $\$ 85$ billion equivalent to $2 \%$, than Housing and Community receiving $\$ 90$ billion $-2 \%$, Transportation receiving $\$ 109$ billion $-3 \%$, Food and Agriculture receiving $\$ 138$ billion - 3\%, and Veterans' Benefits receiving $\$ 179$ billion $-4 \%$. In this year, the greatest beneficiaries of much spending included Military receiving $\$ 632$ billion - $15 \%$, Social Security, Unemployment and Labor receiving \$1.39 trillion - 33\%, and Medicare and Health receiving 1.17 Trillion $-28 \%$. 


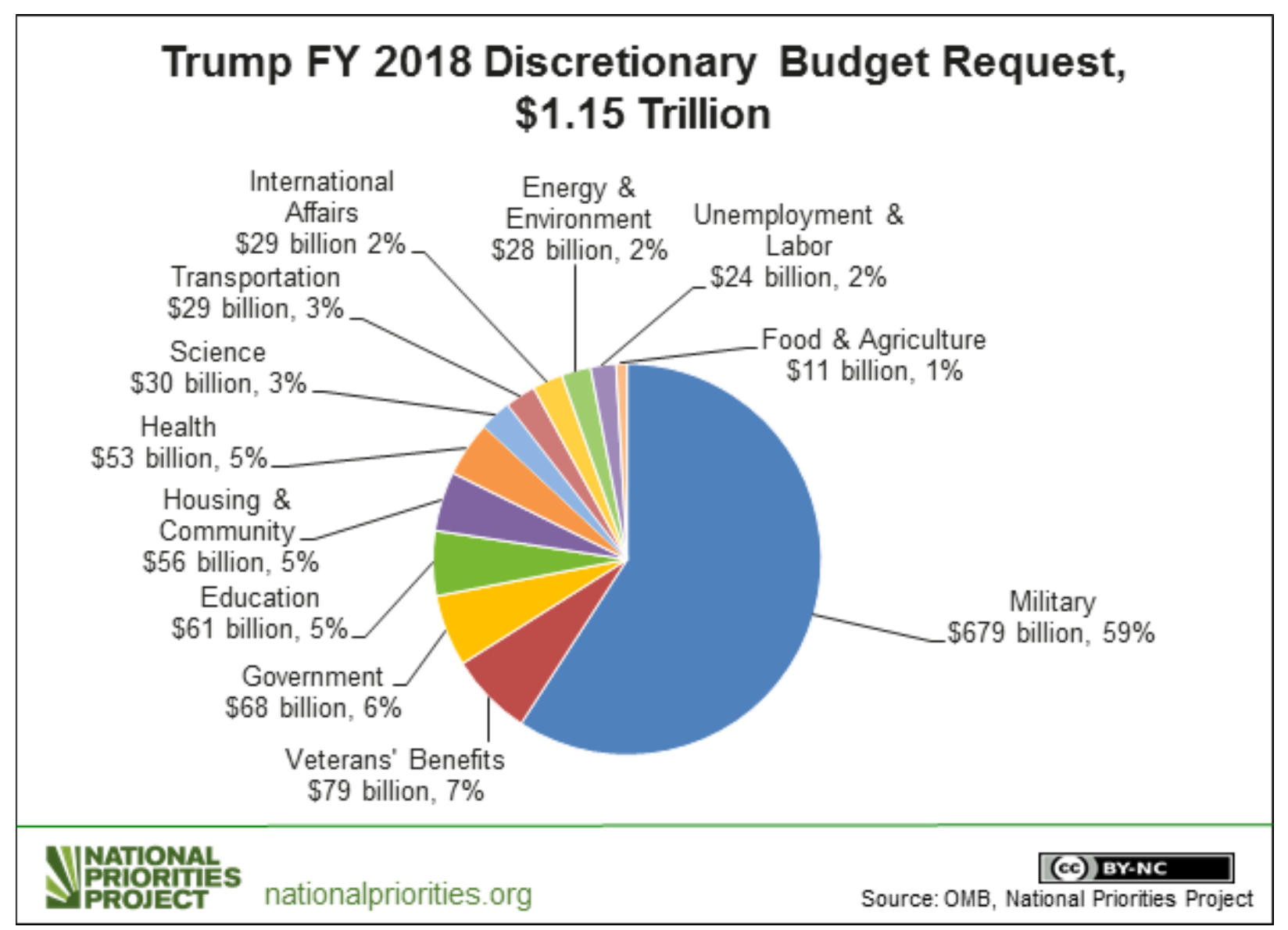

Adapted from nationalpriorities.org

In contrast to many government institutions in the 2018 Discretionary Budget Request, Education Department receives $\$ 61$ billion - 5\%. Indeed, this is more than Health receiving \$53 billion - 5\%, Housing and community $\$ 56$ billion - 5\%, while at the same time, receiving less than Government itself receiving $\$ 68$ billion $-6 \%$, Veterans' Benefits receiving $\$ 79$ billion - 7\%, and Military receiving $\$ 679$ billion - 59\%. 
FIGURE 7

FEDERAL OUTLAYS FOR 2019

\section{Federal Outlays for - FY 2019}

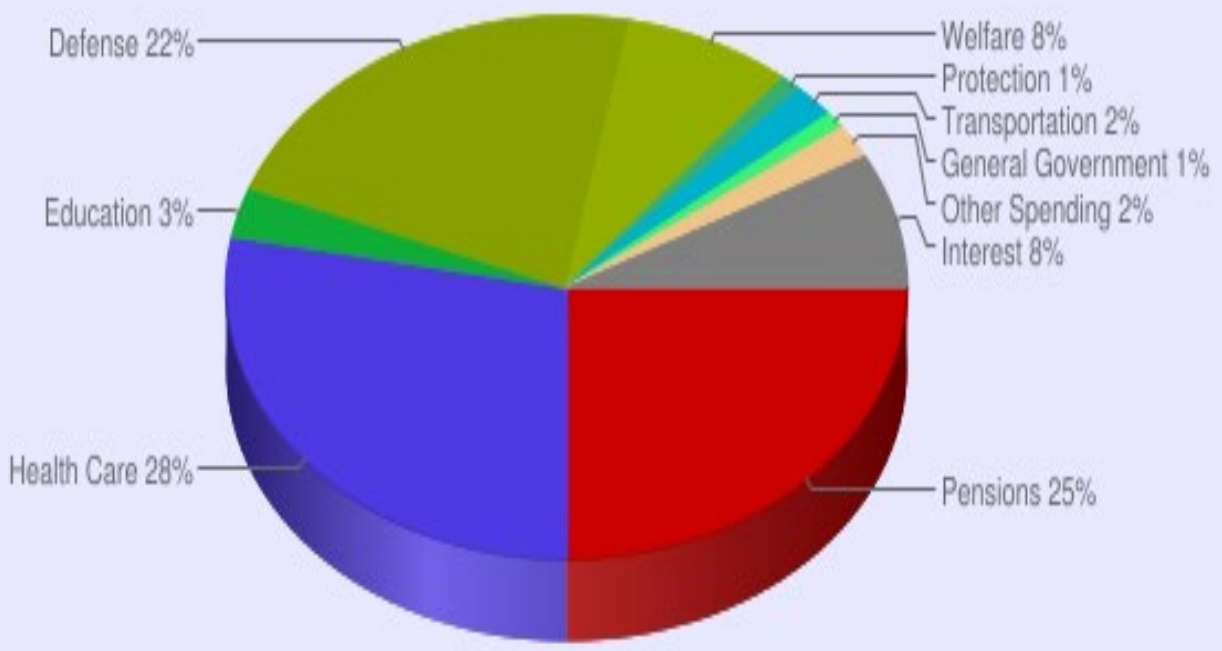

Adopted from Government Spending https://www.usgovernmentspending.com/US_fed_spending_pie_chart

In the 2019 Outlays, you find that Education suffered allocation of funds receiving on 3\% compared to Defense receiving 22\%, Health and Care receiving 28\%, Pensions receiving 25\%, and Welfare receiving $8 \%$. Although 2019 was a year leading to the 2020 elections, education should not have suffered such loss of funds compared to these other big institutions of the government. Undoubtedly, education of the nation's people should be grouped among the three big institutions of the government and a country which should receive a lion's share of the total spending. 


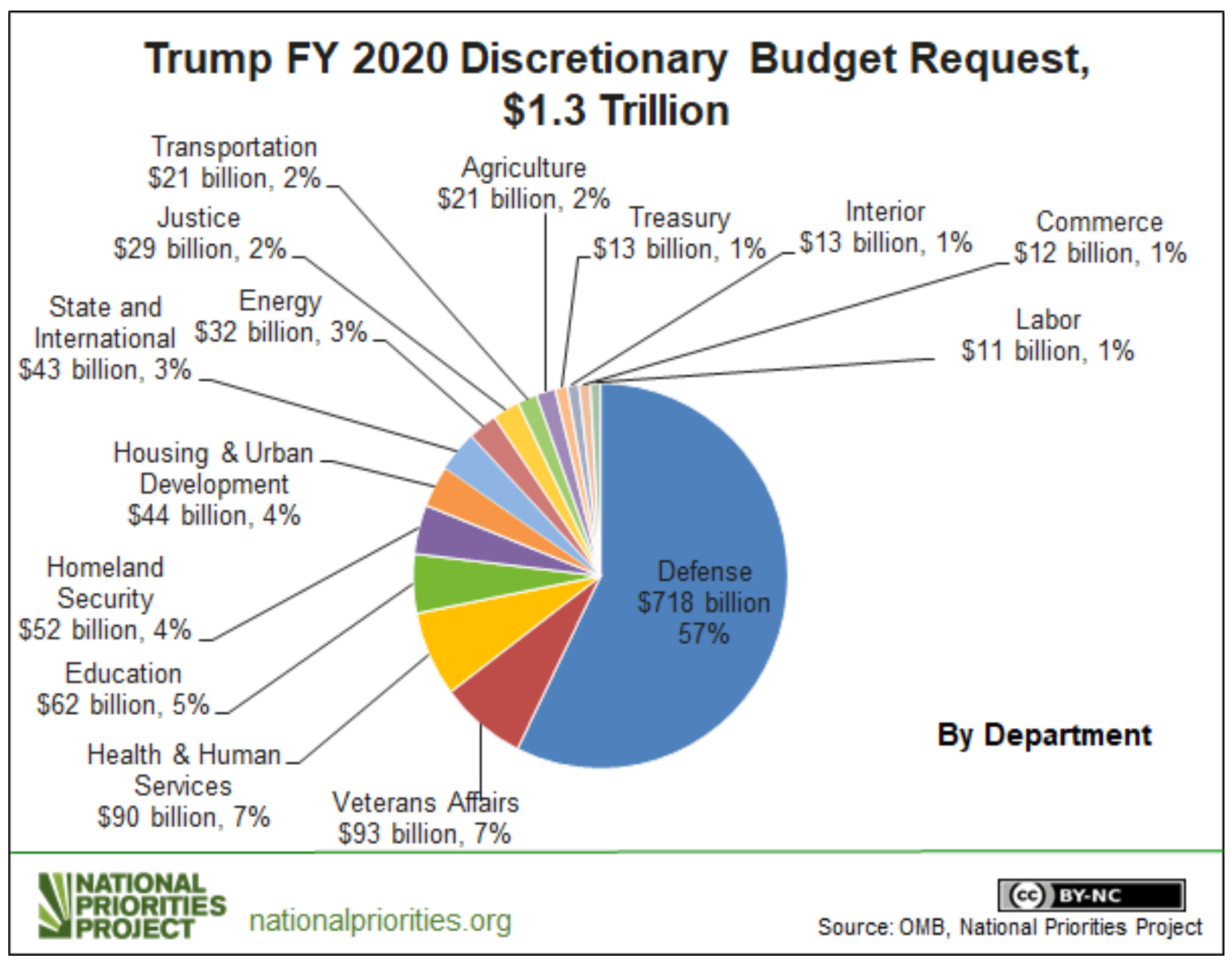

Adapted from nationalpriorities.org

It is fortunate that during the final Trump's 2020 Discretionary Budget Request, Education receives $\$ 62$ billion $-5 \%$. Indeed, this allocation is more than Homeland Security receiving $\$ 52$ billion $-4 \%$, and Housing and Urban Development receiving $\$ 44$ billion - 4\%; but receiving less than Health and Human Services received $\$ 90$ billion - 7\%, Veterans Affairs receiving $\$ 93$ billion - 7\%, and defense which is way out in the 3rd heaven receiving $\$ 718$ billion $-57 \%$.

\section{America Is Affluent}

Economically, America is affluent, and with this wealth, she can educate her citizens adequately, especially the poor and low socioeconomic communities in American's inner cities. Yes, the voluntary and involuntary children of the immigrants should be well-schooled. The majority of them are in rural America, where materials and the digital disparity are rampant. With an education-willed political leadership, America would skyrocket in the education of all its citizens. The analytical data of 2013 to 2020 shows that the budget on education is minimal to meet all academic needs of students, salaries of primary and high school teachers.

The new spirit of privately wealthy Americans might be the solution to educating all her citizens. The billionairess such as Bill Gates, Buffet, Dalio, and Dimon, to mention a few "say that capitalism in its current form simply doesn't work of the rest of the United States" (Rooney, 2019.) Ray Dalio hit is on the 
head, "Capitalism needs to be reformed," (Clifford, 2019, para. 5). These rich people have recognized inequality and an enormous income gap in the capitalist USA, agreeing that there is a need for change for a better society, have proposed to support education (Rooney, 2019, para 2; Clifford, 2019, para). Writers such as Manyika, Punkas, and Tuin adds that capitalism needs to "involve tweaks, reforms or wholesale change" (2020, para. 1).

Any successful system needs reforms to meet the needs of the peoples. With the economic and social change, America should wisely channel the reforms of capitalism to consider providing equitable education for the ever-increasing diverse student population in our K-12 educational system.

One would think that any political regime would look into the education of its people. America is not exempt from this. As we have seen earlier, the government's educational budget is minimal compared with the high budget of the military, which usually has more than half of the total expenditure. The economic and social inequality experienced in the various states of America is due to education, as very well put by Dalio that the disparity is due to "lack of investment in public education" (Cooney, 2019, para.5). Hence, choosing to invest in education is crucial in building an equitable society than the political pushing to socialism. Capitalism's sin is a lack of sharing and channeling money to where it matters, in the education of children, the poor, and the youth development. Education is equalizing instrument, and it's time for America to rise and be doing the right thing, investing in its young's education.

\section{Lessons to Be Learned by America}

There are so many lessons the USA can learn from the educational systems of other countries of the world, including the 3rd world developing countries. The study has shown that though the USA is reaching, its education expenditure is minimal, not where it should be. However, as indicated in this study, wealthy America can learn from Tunisia and Egypt.

Among the things the United States can learn from both Tunisia and Egypt are inequality in funding the education system. The American leaders in the government do not budget more for education, whereas they give a lot of money to other institutions of the government, including defense, Housing Development, Health and Human Services, and Veteran's Benefits.

The second thing to learn is that United States has children from a socioeconomically low background and needs to address the issue. Unfortunately, you have the presence of poverty among millionaires and billionaires. This parity needs mending to allow children of the poor communities' secure education, which consequently helps them come out of poverty and bridge the inequality gap.

The third thing the United States should learn from Tunisia is in the area of empowering women. Though with limited resources, Tunisia is in the front of empowering her women. Indeed, Egypt is working with USAID to reduce gender gaps by "removing constraints to women's economic participation; addressing sexual harassment and gender-based violence; and reducing the gender enrollment gap at all levels of education" (Cristofolleti, 2020, para. 1). Further, Egypt is "improving access for girls to Science, Technology, Engineering, and Mathematics (STEM) education" (Critofolleti, 2020, para. 1). In the United States of America, women have tried to bring themselves out of the low statuses of society by empowering themselves. As developed by Tyack \& Hansot (1992), America must complete the protections and the rights of women and sexual equality as established by the Congress; especially in education and equal employment and salary opportunities as their counterpart and eradication of notions that women are a second class citizens, women treatment as minors, women can't make it without men - they are not complete, and that they can't lead and so forth (Surawicz, 2016; Mill, 2016; Espiritu, 2008; Coleman, 2004; Kessler-Harris, 2003; Durako, 2000).

The government and the leaders have not done enough to prepare women to where they should be. It is pathetic that in America, we speak of human rights, yet being one of the members of the developed nations, we have had no woman president (Baker, Aldrich, \& Nina, 1997; Surawicz, 2016. Is it that women lacked education? Emphatically no. Is it a failure to recognize the women's potential and lack of level grounds for wealth and leadership avenues? For instance, Tanzania got her first female president, Samia Suluhu Hassan, and East Africa feels fantastic that women have broken the ceilings. Indeed, as 3rd world economies, Uganda, Tanzania, and Burundi, though weak and faced with economic and political difficulties 
and corruption in so many ways, have included more women in leadership positions in parliament, senate, and other government leadership positions (Bauer, 2008; Stockemer, 2008; Thorton, 2019). Kenya, as a 3rd world economy, is struggling with the number of women's representation. Still, with the 2010 constitution, which advocates for the two-thirds gender rule in Kenya, women will be gaining political capital (Kaimenyi, Kinya, \& Chege, 2013). A recent study shows that Rwanda (East Africa) was the highest at $61.3 \%$ in women's representation in parliament worldwide. Followed by Cuba with 53.2\%, Bolivia with 53.1\%, Mexico with $48.2 \%$, but the USA lagging at number 75 comes with $23.5 \%$ of women in Congress. What does this tell the world? The USA has a long way to go and has a lot of work to do in allowing the American women who are able and highly educated to lead (Thorton, 2019).

\section{REFERENCES}

Abu-Odeh, L. (2004). Modernizing Muslim family law: The case of Egypt. Vand. J. Transnat'l L., 37, 1043.

Agrawala, S., Moehner, A., El Raey, M., Conway, D., Van Aalst, M., Hagenstad, M., \& Smith, J. (2004). Development and climate change in Egypt: Focus on coastal resources and the Nile. Organisation for Economic Cooperation and Development.

Ajayi, O., Abina, B., \& Lawal, A. (2020). Government policies on education in Africa. In Understanding the Higher Education Market in Africa (pp. 37-50). Routledge.

Akkari, A. (2004). Education in the Middle East and North Africa: The current situation and future challenges. International Education Journal, 5(2), 144-153.

Al-Ali, N., Ali, N.S., \& Nadje, A.A. (2000). Secularism, gender and the state in the Middle East: The Egyptian women's movement (Vol. 14). Cambridge University Press.

Alexander, C. (2010). Tunisia: stability and reform in the modern Maghreb. Routledge.

Anderson, L. (2014). The state and social transformation in Tunisia and Libya, 1830-1980. Princeton University Press.

Anzar, U. (2003). Islamic education: A brief history of madrassas with comments on curricula and current pedagogical practices. Paper for the University of Vermont, Environmental Programme.

Arfaoui, K. (2011). Women and education in Tunisia: From independence to the Jasmine Revolution. Women's Studies North and South, 37.

Arieff, A. (2011). Tunisia: Recent Developments and Policy Issues. Congressional Research Service.

Arieff, A., \& Humud, C.E. (2011). Political transition in Tunisia (Vol. 15). Washington, DC: Congressional Research Service.

Aspfors, J., \& Fransson, G. (2015, April). A metasynthesis of research on mentor education: Three emerging dimensions. In American Educational Research Association (AERA) Annual Meeting (pp. 16-20). Chicago, USA.

Assad, R., \& Barsoum, G. (2007). Youth Exclusion in Egypt: In Search of 'Second Chances'. Middle East Youth Initiative Working Paper, (2).

Azoury, N. (Ed.). (2017). Business and Society in the Middle East: Exploring Responsible Business Practice. Springer.

Badr, G.M. (1977). Islamic law: Its relation to other legal systems. Am. J. Comp. L., 26, 187.

Bair, C.R., \& Haworth, J.G. (2004). Doctoral student attrition and persistence: A meta-synthesis of research. In Higher education: Handbook of theory and research (pp. 481-534). Springer, Dordrecht.

Baker, G. (1917). A List of Soldiers of the Various Wars, Buried in the Frankfort Cemetery at Frankfort, Kentucky. Register of Kentucky State Historical Society, pp. 79-85.

Baker, T., E. Aldrich, H., \& Nina, L. (1997). Invisible entrepreneurs: The neglect of women business owners by mass media and scholarly journals in the USA. Entrepreneurship \& Regional Development, 9(3), 221-238. 
Baraka, P.E. (2008). Citizenship education in Egyptian public schools: What values to teach and in which administrative and political contexts. Journal of Education for International Development, 3(3), $1-18$.

Barakat, M.R., Elgazzar, S.H., \& Hanafy, K.M. (2016). Impact of macroeconomic variables on stock markets: Evidence from emerging markets. International Journal of Economics and Finance, 8(1), 195-207.

Barkey, K., \& Gavrilis, G. (2016). The Ottoman millet system: Non-territorial autonomy and its contemporary legacy. Ethnopolitics, 15(1), 24-42.

Battenburg, J. (1997). English versus French: language rivalry in Tunisia. World Englishes, 16(2), 281290.

Bauer, G. (2008). Fifty/fifty by 2020: Electoral gender quotas for parliament in east and southern Africa. International Feminist Journal of Politics, 10(3), 348-368.

Bazeley, P. (2017). Integrating analyses in mixed methods research. Sage.

Beissinger, M.R., Jamal, A.A., \& Mazur, K. (2015). Explaining divergent revolutionary coalitions: Regime strategies and the structuring of participation in the Tunisian and Egyptian revolutions. Comparative Politics, 48(1), 1-24.

Belloumi, M. (2014). The relationship between trade, FDI and economic growth in Tunisia: An application of the autoregressive distributed lag model. Economic systems, 38(2), 269-287.

Benjamin Stachursky. (2013). The Promise and Perils of Transnationalization: NGO Activism and the Socialization of Women's Human Rights in Egypt and Iran (Vol. 102). Routledge.

Beyer, S., Jensen, G., Johnson, R., Jeribi, A., Fakhfekh, M., \& Jarboui, A. (2015). Tunisian revolution and stock market volatility: Evidence from FIEGARCH model. Managerial Finance.

Biavaschi, C., Eichhorst, W., Giulietti, C., Kendzia, M.J., Muravyev, A., Pieters, J., . . Zimmermann, K.F. (2012). Youth unemployment and vocational training.

Biygautane, M. (2015). Anti-Corruption Strategies in the Gulf Cooperation Council's States: Lessons learned and the path forward. Government Anti-Corruption Strategies: A cross-cultural perspective, pp. 187-214.

Boittin, J.A. (2010). Feminist mediations of the exotic: French Algeria, Morocco and Tunisia, 192139. Gender \& History, 22(1), 131-150.

Bouhlila, D.S. (2011). The quality of secondary education in the Middle East and North Africa: What can we learn from TIMSS'results? Compare, 41(3), 327-352.

Boyle, H.N. (2006). Memorization and learning in Islamic schools. Comparative Education Review, $50(3), 478-495$.

Bozeman, A.B. (2017). Politics and culture in international history: From the ancient Near East to the opening of the modern age. Routledge.

Brady, K., Eatman, T., \& Parker, L. (2000). To have or not to have? A preliminary analysis of higher education funding disparities in the post-Ayers v. Fordice era: Evidence from critical race theory. Journal of Education Finance, 25(3), 297-322.

Breuer, A., Landman, T., \& Farquhar, D. (2015). Social media and protest mobilization: Evidence from the Tunisian revolution. Democratization, 22(4), 764-792.

Burçak, B. (2008). Modernization, science and engineering in the early nineteenth century Ottoman Empire. Middle Eastern Studies, 44(1), 69-83.

Cain, P.J. (2006). Character and imperialism: The British financial administration of Egypt, 18781914. Journal of Imperial and Commonwealth History, 34(2), 177-200.

Çelik, Z. (1993). The remaking of Istanbul: Portrait of an Ottoman city in the nineteenth century (No. 2). Univ of California Press.

Charrad, M.M. (1997). Policy shifts: State, Islam, and gender in Tunisia, 1930s-1990s. Social Politics: International Studies in Gender, State \& Society, 4(2), 284-319.

Charrad, M.M. (2012). Family law reforms in the Arab world: Tunisia and Morocco. New York. 
Clifford, C. (2019, December 31). What billionaires said about wealth inequality and capitalism in 2019. Retrieved from https://www.cnbc.com/2019/12/31/what-billionaires-said-about-wealth-inequalityand-capitalism-in-2019.html

Cochran, J. (2012). Education in Egypt (RLE Egypt) (Vol. 1). Routledge.

Coleman, I. (2004). The payoff from women's rights. Foreign Aff., 83, 80.

Coleman, J.S. (2015). Education and Political Development (SPD-4) (Vol. 4). Princeton University Press.

Cook, B.J. (1999). Islamic versus Western conceptions of education: Reflections on Egypt. International Review of Education, 45(3-4), 339-358.

Cook, B.J. (2001). Islam and Egyptian higher education: Student attitudes. Comparative Education Review, 45(3), 379-411.

Crisman, K., Lees, W.B., \& Davis, J. (2013). The Western River Steamboat Heroine, 1832-1838, Oklahoma, USA: Excavations, summary of finds, and history. International Journal of Nautical Archaeology, 42(2), 365-381.

Critofolleti, T. (2020). Gender Equality and Women's Empowerment. USAID - From the American People. Retrieved from https://www.usaid.gov/egypt/gender-equality-and-womens-empowerment

Dalmasso, E., \& Cavatorta, F. (2010). Reforming the family code in Tunisia and Morocco-the struggle between religion, globalisation and democracy. Totalitarian Movements and Political Religions, 11(2), 213-228.

Dang, H.A., \& Rogers, F.H. (2008). The growing phenomenon of private tutoring: Does it deepen human capital, widen inequalities, or waste resources? The World Bank Research Observer, 23(2), 161200.

Daoud, M. (2001). The language situation in Tunisia. Current Issues in Language Planning, 2(1), 1-52.

Daoud, M. (2007). The language situation in Tunisia. In Language Planning and Policy in Africa, Vol. 2 (pp. 256-307). Multilingual Matters.

Daoud, M. (2011). The sociolinguistic situation in Tunisia: Language rivalry or accommodation?

Denzin, N.K. (2010). Moments, mixed methods, and paradigm dialogs. Qualitative Inquiry, 16(6), 419427.

Doğan, M.A. (2011). American Missionaries and the Middle East: Foundational Encounters. University of Utah Press.

Durako, J.A. (2000). Second-Class Citizens in the Pink Ghetto: Gender Bias in Legal Writing. Journal of Legal Education, 50(4), 562-5.

Dwyer, K. (1991). Arab Voices: The human rights debate in the Middle East (Vol. 13). Univ of California Press.

El-Said, H., \& Harrigan, J. (2014). Economic reform, social welfare, and instability: Jordan, Egypt, Morocco, and Tunisia, 1983-2004. The Middle East Journal, 68(1), 99-121.

Eltkhtash, S. (2013). Internet financial reporting in Arab MENA countries.

Erhan, Ç. (2000). Ottoman official attıtudes towards American missionaries. The Turkish Yearbook of International Relations, (30), 191-212.

Esmaeili, H. (2010). The nature and development of law in Islam and the rule of law challenge in the Middle East and the Muslim World. Conn. J. Int'l L., 26, 329.

Faksh, M.A. (1980). The consequences of the introduction and spread of modern education: Education and national integration in Egypt. Middle Eastern Studies, 16(2), 42-55.

Faour, M. (2012). Religious education and pluralism in Egypt and Tunisia. Washington, DC: Carnegie Endowment for International Peace.

Faour, M. (2013). A review of citizenship education in Arab nations (Vol. 20). Washington, DC: Carnegie Endowment for International Peace.

Faour, M. (2014, October). Teaching Religion in Egypt and Tunisia A Challenge to Citizenship Education. In Policies and Politics of Teaching Religion (pp. 21-38). Nomos Verlagsgesellschaft $\mathrm{mbH} \& \mathrm{Co} . \mathrm{KG}$.

Feuer, S.J. (2014). Religious Establishment and Regime Survival: The Politics of Religious Education in Morocco and Tunisia, 1956-2010. Brandeis University. 
Feuer, S.J. (2017). Regulating Islam: Religion and the state in contemporary Morocco and Tunisia. Cambridge University Press.

Frini, O., \& Muller, C. (2012). Demographic transition, education and economic growth in Tunisia. Economic Systems, 36(3), 351-371.

Galbraith, J.S., \& al-Sayyid-Marsot, A.L. (1978). The British occupation of Egypt: Another view. International Journal of Middle East Studies, pp. 471-488.

Ghaith, G., \& Shabaan, K. (1996). Language-in-education policy and planning: The case of Lebanon. Mediterranean Journal of Educational Studies, 1(2), 95-105.

Göçek, F.M. (1993). Ethnic Segmentation, Western Education, and Political Outcomes: NineteenthCentury Ottoman Society. Poetics Today, pp. 507-538.

Goodwin, J. (2002). Price of honor: Muslim women lift the veil of silence on the Islamic world. Penguin.

Grami, A. (2008). Gender equality in Tunisia. British Journal of Middle Eastern Studies, 35(3), 349-361.

Harrigan, J.R., \& El-Said, H. (2010). The economic impact of IMF and World Bank programs in the Middle East and North Africa: A case study of Jordan, Egypt, Morocco and Tunisia, 1983-2004. Review of Middle East Economics and Finance, 6(2), 1-25.

Hasse, K.V. (2015). Explaining the Arab Uprisings of 2011: The Origins and Outcomes of Contagion. (Doctoral dissertation, University of Johannesburg).

Hatem, M.F. (1992). Economic and political liberation in Egypt and the demise of state feminism. International Journal of Middle East Studies, 24(2), 231-251.

Hatem, T. (1994). Egypt: Exploring management in the Middle East. International Studies of Management \& Organization, 24(1-2), 116-136.

Haverkamp, B.E., \& Young, R.A. (2007). Paradigms, purpose, and the role of the literature: Formulating a rationale for qualitative investigations. The Counseling Psychologist, 35(2), 265-294.

Helmy, H.E. (2013). The impact of corruption on FDI: Is MENA an exception? International Review of Applied Economics, 27(4), 491-514.

Henry, C.M., \& Springborg, R. (2010). Globalization and the Politics of Development in the Middle East (Vol. 1). Cambridge University Press.

Hessini, L. (2007). Abortion and Islam: Policies and practice in the Middle East and North Africa. Reproductive Health Matters, 15(29), 75-84.

Holmes, M.T.E. (2008). Higher education reform in Egypt: Preparing graduates for Egypt's changing political economy. Education, Business and Society: Contemporary Middle Eastern Issues.

Horowitz, R.S. (2004). International law and state transformation in China, Siam, and the Ottoman Empire during the nineteenth century. Journal of World History, pp. 445-486.

Hyde, G.D. (2013). Education in modern Egypt (RLE Egypt): Ideals and realities. Routledge.

Ibrahim, A.S. (2010). The politics of educational transfer and policymaking in Egypt. Prospects, 40(4), 499-515.

Ille, S. (2015). Private Tutoring in Egypt: Quality Education in a Deadlock between Low Income, Status and Motivation. Egyptian Center for Economic Studies Working Paper No, 178.

Irani, G.E., \& Funk, N.C. (1998). Rituals of reconciliation: Arab-Islamic perspectives. Arab Studies Quarterly, pp. 53-73.

Isakhan, B., Mansouri, F., \& Akbarzadeh, S. (2012). ISS 12 The Arab Revolutions in Context: Civil Society and Democracy in a Changing Middle East. Melbourne Univ. Publishing.

Isakhan, B., Mansouri, F., \& Akbarzadeh, S. (Eds.). (2012). ISS 12 The Arab Revolutions in Context: Civil Society and Democracy in a Changing Middle East. Melbourne Univ. Publishing.

Jamali, D., Lanteri, A., \& Walburn, A. (2013). Corruption and economic security in the Arab countries: The role of business schools. International Journal of Sustainable Human Security, 1(1), 156-177.

Jules, T.D., \& Bouhlila, D.S. (2018, December). Indirect coercive transfer and educational copying under dictatorship: The case of Tunisia. In FIRE: Forum for International Research in Education (Vol. 4, No. 3).

Kaboub, F. (2013). The making of the Tunisian Revolution. Middle East Development Journal, 5(01), 1350003. 
Kaimenyi, C., Kinya, E., \& Chege, S.M. (2013). An analysis of affirmative action: The two-thirds gender rule in Kenya. International Journal of Business, Humanities and Technology, 3(6), 91-97.

Kapoor, I. (2020). 9. Perversion/Hysteria: The Politics of Perversion and Hysteria in the Tunisian Revolution and Its Aftermath. In Confronting Desire (pp. 194-213). Cornell University Press.

Katz, K. (2012). URBAN IDENTITY IN COLONIAL TUNISIA: THE "MAQĀMĀT" OF SALIH SUWAYSI AL-QAYRAWANI. International Journal of Middle East Studies, 44(4), 693-712. Retrieved May 27, 2021, from http://www.jstor.org/stable/23280426

Kchih, H., Perrino, C., \& Cherif, S. (2015). Investigation of desert dust contribution to source apportionment of PM10 and PM2. 5 from a southern Mediterranean coast. Aerosol Air Qual. Res, 15, 454-464.

Kessler-Harris, A. (2003). Out to work: A history of wage-earning women in the United States. Oxford University Press.

Kuhnke, L. (1990). Lives at risk: Public health in nineteenth-century Egypt (Vol. 24). Univ of California Press.

Kupchan, C.A. (2012). The decline of the West: Why America must prepare for the end of dominance. The Atlantic, 20(3). Retrieved from https://www.theatlantic.com/international/archive/2012/03/the-decline-of-the-west-why-americamust-prepare-for-the-end-of-dominance/254779/

Le Espiritu, Y. (2008). Asian American women and men: Labor, laws, and love. Rowman \& Littlefield.

Leland, A. (2010). American war and military operations casualties: Lists and statistics. DIANE Publishing.

Lewis, M.D. (2013). Divided Rule: Sovereignty and Empire in French Tunisia, 1881Đ1938. Univ of California Press.

Littrell, R.F., \& Bertsch, A. (2013). UN Millennium Development Goals and gender equality in employment in the Middle East. Foresight-The Journal of Future Studies, Strategic Thinking and Policy, 15(4), 249-263.

Lloyd, C.B., El Tawila, S., Clark, W.H., \& Mensch, B.S. (2003). The impact of educational quality on school exit in Egypt. Comparative Education Review, 47(4), 444-467.

Loveluck, L. (2012). Education in Egypt: Key challenges. Universitäts-und Landesbibliothek.

Mackenzie, N., \& Knipe, S. (2006). Research dilemmas: Paradigms, methods and methodology. Issues in Educational Research, 16(2), 193-205.

Mahoney, P.G. (2001). The common law and economic growth: Hayek might be right. The Journal of Legal Studies, 30(2), 503-525.

Makdisi, U. (2000). The culture of sectarianism: community, history, and violence in nineteenth-century Ottoman Lebanon. Univ of California Press.

Makdisi, U. (2011). Artillery of heaven: American missionaries and the failed conversion of the Middle East. Cornell University Press.

Manyika, J., Pinkus, G., \& Tuin, M. (2020, November 12). Rethinking the future of American capitalism. Retrieved from https://www.mckinsey.com/featured-insights/long-term-capitalism/rethinking-thefuture-of-american-capitalism

Marchesi, U. (2017). The resilience of Arab monarchies during the uprisings of 2011 and 2012: The Hashemite Kingdom of Jordan.

Mashhour, A. (2005). Islamic law and gender equality: Could there be a common ground? A study of divorce and polygamy in Sharia Law and contemporary legislation in Tunisia and Egypt. Human Rights Quarterly, pp. 562-596.

Matta, S., Appleton, S., \& Bleaney, M. (2018). The microeconomic impact of political instability: Firmlevel evidence from Tunisia. Review of Development Economics, 22(4), 1590-1619.

Mayer, A.E. (1995). Reform of personal status laws in North Africa: A problem of Islamic or Mediterranean laws? The Middle East Journal, pp. 432-446.

Mckay, D.V. (1945). The French in Tunisia. Geographical Review, 35(3), 368-390 
Mertens, D.M. (2014). Research and evaluation in education and psychology: Integrating diversity with quantitative, qualitative, and mixed methods. Sage publications.

Middleton, J., \& Demsky, T. (1989). Vocational Education and Training: A Review of World Bank Investment. World Bank Discussion Papers 51. World Bank Publications, 1818 H Street, NW, Washington, DC 20433.

Middleton, J., \& Ziderman, A. (1997). Overview: World Bank policy research on vocational education and training. International Journal of Manpower.

Mir-Hosseini, Z. (2006). Muslim women's quest for equality: Between Islamic law and feminism. Critical Inquiry, 32(4), 629-645.

Mnif, A.T. (2017). Political uncertainty and behavior of Tunisian stock market cycles: Structural unobserved components time series models. Research in International Business and Finance, 39, 206-214.

Moon, B. (2007). School-based teacher development in Sub-Saharan Africa: Building a new research agenda. The Curriculum Journal, 18(3), 355-371.

Mortimer-Murphy, K. (2020). French and British Policy and Culture in Egypt 1798-1841: The Reign of Muhammad Ali and the Eastern Crisis. Doctoral dissertation, Flinders University, College of Humanities, Arts and Social Sciences.

Murphy, E.C. (1996). Women in Tunisia: A survey of achievements and challenges. The Journal of North African Studies, 1(2), 138-156.

Murphy, E.C. (2003). Feminism and Economic Reform. Women and Globalization in the Arab Middle East: Gender, Economy, and Society, 169.

Naciri, A. (2015). Credit rating governance: Global credit gatekeepers. Routledge.

Neill, C.M. (2006). Islam in Egyptian education: Grades K-12. Religious Education, 101(4), 481-503.

Nugent, J.B. (2012). Detecting corruption and evaluating programs to control it: Some lessons for MENA. Corruption and Economic Development, 11.

Nye, E., Melendez-Torres, G.J., \& Bonell, C. (2016). Origins, methods and advances in qualitative metasynthesis. Review of Education, 4(1), 57-79.

O’Sullivan, A., Rey, M.E., \& Mendez, J.G. (2011). Opportunities and Challenges in the MENA Region. Arab World Competitiveness Report, 2012, 42-67.

Obermeyer, C.M. (1994). Reproductive choice in Islam: Gender and state in Iran and Tunisia. Studies in Family Planning, pp. 41-51.

Odeh, L.M. (2012). State of Global Financial Crime In-depth Analysis on GCC Countries. (Doctoral dissertation, The British University in Dubai (BUiD).

Oketch, M.O. (2007). To vocationalise or not to vocationalise? Perspectives on current trends and issues in technical and vocational education and training (TVET) in Africa. International Journal of Educational Development, 27(2), 220-234.

Oreopoulos, P. (2006). Estimating average and local average treatment effects of education when compulsory schooling laws really matter. American Economic Review, 96(1), 152-175.

Oxford Analytica. (2016). Structural barriers will hold back Tunisian economy. Emerald Expert Briefings, (oxan-db).

Pellicer, M., Assaad, R., Krafft, C., \& Salemi, C. (2017, June). Grievances or skills? The effect of education on youth attitudes and political participation in Egypt and Tunisia. Dokki: Economic Research Forum.

Perkins, K. (2014). A history of modern Tunisia. Cambridge University Press.

Pikkert, P. (2008). Protestant missionaries to the Middle East: Ambassadors of Christ or culture? Doctoral dissertation.

Pilkey, O., Heron, D., Harbridge, W., Kamens, J., Keer, F., \& Thornton, S. (1989). The sedimentology of three Tunisian lagoons. Marine Geology, 88(3-4), 285-301.

Plaetzer, N. (2014). Civil society as domestication: Egyptian and Tunisian uprisings beyond liberal transitology. Journal of International Affairs, pp. 255-265. 
Qutb, R.M. (2016). Analyzing the external and internal efficiency considerations in public subsidization of education in Egypt. Journal of Economics and Sustainable Development, 7(12).

Rane, H., \& Salem, S. (2012). Social media, social movements and the diffusion of ideas in the Arab uprisings. Journal of International Communication, 18(1), 97-111.

Rooney, K. (2019). Finance. American billionaires call for upgrades to capitalism, starting with higher taxes on themselves. Retrieved from https:/www.cnbc.com/2019/04/08/american-billionairescall-for-upgrades-to-capitalism-starting-with-higher-taxes-on-themselves.html

Sayed, F.H. (2006). Transforming education in Egypt: Western influence and domestic policy reform. American Univ in Cairo Press.

Schomaker, R. (2015). Accreditation and quality assurance in the Egyptian higher education system. Quality Assurance in Education.

Shabaya, J., \& Konadu-Agyemang, K. (2004). Unequal access, unequal participation: Some spatial and socio-economic dimensions of the gender gap in education in Africa with special reference to Ghana, Zimbabwe and Kenya. Compare: A Journal of Comparative and International Education, 34(4), 395-424.

She, C.L. (2012). Breaking the silence: Nationalism and feminism in contemporary Egyptian women's writing. Doctoral dissertation, University of Leicester.

Siala, M., \& Ammar, N.B. (2014). Vocational and General Education of Girls and Boys in Tunisia: The Effects of Income and Parental Education. Eurasian Journal of Social Sciences, 2(1), 11-19.

Sobhy, H. (2012). The de-facto privatization of secondary education in Egypt: A study of private tutoring in technical and general schools. Compare: A Journal of Comparative and International Education, 42(1), 47-67.

Starrett, G. (1998). Putting Islam to work: Education, politics, and religious transformation in Egypt (Vol. 25). Univ of California Press.

Staudt, K. (Ed.). (2010). Women, International Development: And Politics. Temple University Press. Stepan, A. (2012). Tunisia's transition and the twin tolerations. Journal of Democracy, 23(2), 89-103.

Stockemer, D. (2011). Women's parliamentary representation in Africa: The impact of democracy and corruption on the number of female deputies in national parliaments. Political Studies, 59(3), 693-712.

Subramanian, K. (2016). The Money Laundering and Financing of Terrorism Eco-system. Notion Press.

Sultana, R.G. (2004). Tunisia's quest for educational quality: Introducing the competency approach in primary schooling.

Surawicz, C.M. (2016). Women in leadership: Why so few and what to do about it. Journal of the American College of Radiology, 13(12), 1433-1437.

Talani, L.S. (2015). The Political Economy of migration from the MENA area before and after the Arab Spring: The case of Tunisia and Egypt. In Handbook of the International Political Economy of Migration. Edward Elgar Publishing.

Thornton, A. (2019). These countries have the most women in parliament. World Economic Forum. Retrieved from https://www.weforum.org/agenda/2019/02/chart-of-the-day-these-countries-havethe-most-women-in-parliament/

Tyack, D., \& Hansot, E. (1992). Learning together: A history of coeducation in American public schools. Russell Sage Foundation.

Valverde, G.A. (2005). Curriculum policy seen through high-stakes examinations: Mathematics and biology in a selection of school-leaving examinations from the Middle East and North Africa. Peabody Journal of Education, 80(1), 29-55.

Walsh, D., \& Downe, S. (2005). Meta-synthesis method for qualitative research: A literature review. Journal of Advanced Nursing, 50(2), 204-211.

Wexler, N. (2020). The Knowledge Gap: The Hidden Cause of America's Broken Education System--And How to Fix It. Retrieved from https://www.porchlightbooks.com/product/knowledge-gap-thehidden-cause-of-americas-broken-education-system--and-how-to-fix-it--nataliewexler?variationCode $=9780735213555$ 
Wilder, S. (2014). Effects of parental involvement on academic achievement: A meta-synthesis. Educational Review, 66(3), 377-397.

Willis, J.W., Jost, M., \& Nilakanta, R. (2007). Foundations of qualitative research: Interpretive and critical approaches. Sage.

Wing, A.K., \& Kassim, H. (2007). The Future of Palestinian Women's Rights: Lessons from a HalfCentury of Tunisian Progress. Wash. \& Lee L. Rev., 64, 1551.

Yaghi, M. (2018). Frame Resonance, Tactical Innovation, and Poor People in the Tunisian Uprising. In Research in Social Movements, Conflicts and Change. Emerald Publishing Limited.

Yanow, D., \& Schwartz-Shea, P. (2015). Interpretation and method: Empirical research methods and the interpretive turn. Routledge.

Yount, K.M. (2004). Symbolic gender politics, religious group identity, and the decline in female genital cutting in Minya, Egypt. Social Forces, 82(3), 1063-1090.

Youssef, A.B. (2018). Migration Analysis of Credit Risk in Tunisian Banking Sector. Indian Journal of Finance and Banking, 2(1), 34-43.

Zaiane, S. (2018). The impact of political instability driven by the Tunisian revolution on stock market volatility: Evidence from sectorial indices. Journal of Applied Business Research (JABR), 34(2), $339-354$.

Zakharia, Z. (2009). Positioning Arabic in Schools. In Critical approaches to comparative education (pp. 215-231). Palgrave Macmillan, New York.

Zdanowski, J. (2014). Middle Eastern societies in the 20th century. Cambridge Scholars Publishing. 